\title{
Országeredet-hatás vagy országeredet-hatások? Az országeredet-hatás összefüggéseinek vizsgálata az Opel márka példáján
}

\author{
Kovács László - Németh Tamás \\ Eöłvös Loránd Tudományegyetem
}

\begin{abstract}
A TANULMÁNY CÉLJA
A tanulmány célja egy empirikus, márkaasszociációs kutatás eredményei alapján rávilágítani arra, hogy az országeredet-hatás sok esetben nem egyszerüsíthető le egy ország hatására: elképzelhető, hogy egy termék esetében több országeredet versenyez egymással. Ezek a versengő országeredetek különböző eszközökkel tudatosíthatóak és megfelelően felhasználva a márka pozicionálására használhatóak.
\end{abstract}

\begin{abstract}
ALKALMAZOTT MÓDSZERTAN
A tanulmány empirikus részében az országeredet-hatás egyes aspektusait vizsgáljuk az Opel márka esetében. A kutatás során szabad és irányított asszociációkat gyüjtöttünk online, mind az országeredethez kapcsolt termékkategóriával, mind a márkával kapcsolatban.
\end{abstract}

\section{LEGFONTOSABB EREDMÉNYEK}

Az eredmények alapján az Opel márkát a válaszadók jelenleg is német márkának tekintik: a márkát explicit módon német márkaként nevezik meg és a márkával kapcsolatos asszociációik is a német autómárkákra jellemző asszociációkkal harmonizálnak. Az eredmények és a szakirodalom alapján az országeredet-hatást befolyásoló tényezőket továbbgondolva javasoljuk az eredeti, aktuális, sugallt és vélt országeredet fogalmának bevezetését.

\section{GYAKORLATI JAVASLATOK}

Az eredmények alapján javasoljuk az Opel márka kettős országeredetének (német és francia) hangsúlyozását a marketingkommunikáció kiemelt elemeként, illetve a márkához kapcsolódó nyelvi elemek között egyaránt. A kettős országeredet hangsúlyozása olyan egyedi pozicionálást tesz lehetővé, amely a mindkét országeredetből származó kedvező asszociációkat egyszerre kapcsolja a márkához.

Kulcsszavak: Opel, országeredet, asszociációk, országeredet-hatás

DOI: 10.15170/MM.2020.54.03.06 


\section{BEVEZETÉS INTRODUCTION}

Ha a Magyarországon az 1990-es években végbement gazdasági változások jelképét kellene megtalálni, valószínủleg sokan az Opel Astra és a Suzuki Swift gépkocsikat említenék elöször. Az 1990-es évek közepe óta a magyarországi utcaképtől elválaszthatatlan volt az Opel márka jellegzetes, Astra F típusa. Az ezredfordulón megjelent ennek az elnyűhetetlen típusnak az újabb generációja, és már az Astra $\mathrm{G}$ is színesítette az utcaképet a Corsákkal, a Vectrákkal és az Omegákkal együtt.

Az elmúlt évek gazdasági híradásaiban ismét kiemelt figyelmet kapott az Opel: a német alapítású, majd sokáig a General Motors tulajdonában lévő márkát 2017-ben megvásárolta a francia Groupe PSA, a Peugeot, a Citroën és a DS márkák tulajdonosa.

A tanulmányban az országeredet-hatást vizsgáljuk több összefüggésben, rámutatva, hogy egy termék országeredete nem minden esetben egyértelmü, és az országeredet-hatást számos tényező befolyásolhatja. Ehhez először leírjuk az országeredet-hatás alkotóelemeit, majd a kutatás empirikus részében arra a kérdésre keressük a választ asszociációk segítségével, hogy az Opel márka milyen pozíciót foglal el a fogyasztók fejében: azt német, vagy inkább francia márkának tekintik-e? Az empirikus kutatás eredményei alapján rámutatunk az országeredet-kérdés komplexitására és bevezetjük az eredeti, a valós a sugallt és a vélt országeredet fogalmát. A tanulmány utolsó részében javaslatokat teszünk arra, hogyan lehet az Opel márka jelenlegi „kettős” országeredetét - egyszerre német és francia márka - pozicionálásra felhasználni.

\section{ORSZÁGEREDET COUNTRY-OF-ORIGIN (COO)}

Az országeredet-hatás az 1960-as évek közepén jelent meg új kutatási irányként a marketingen belül (Matarazzo 2012). A terület irodalma ma már nagyon szerteágazó - 2002-ben is több mint 750 tanulmányt tartottak számon a témában (Papp-Váry 2017) - és fogalma számos kontextusban értelmezhető (vö. Malota 2004a, 2004b, Matarazzo 2012, Papp-Váry 2019, Törőcsik - Somogyi 2009).

$\mathrm{Az}$ országeredet-hatás alatt azt értjük, hogy „miként látnak a fogyasztók egy adott országból érkező terméket" (Roth és Romeo alapján PappVáry 2004, 301). Az országeredet-hatás vizsgálatával így azt elemezhetjük, hogy miként befolyásolja egy adott termék megítélését, ha az egy adott országból származik. Amennyiben egy termék egy olyan országból származik, amelyet összekapcsolunk az adott termékkategóriával, akkor a hatás pozitív, amennyiben viszont a termékkategória „,nem jellemző" adott országra, akkor a hatás negatív is lehet (Adina et al. 2015). A fogyasztók hajlandóak magasabb összeget is fizetni egy olyan termékért, ami egy olyan országból származik, ahol adott termék gyártása már hosszabb múltra tekint vissza, és amely ország „szakértője” adott termékkategóriának - mint például a német autók vagy a francia parfümök (Törőcsik - Somogyi 2009).

Az országeredet kérdése, és az országeredethatás azonban ma már sok esetben nem egyszerúsíthető le egy összefüggésre. Így már beszélhetünk termékekkel kapcsolatban a country-of-manufacturing (COM), a country-of-assembly (COA), a country-of-parts (COP), a country-of-design (COD) és a country-of-brand (COB) fogalmáról (Aichner 2014, vö. Matarazzo 2012). A kontextusban a hibrid termék koncepciója is megjelent: hibrid termék az, amelynek országeredete nem egyértelmủen meghatározható (Chao 1993).

A country-of-assembly (összeszerelés országa) és a country-of-design (terméktervezés országa) fogalma már az 1990-es évek elején szétvált. Az összeszerelés országának hatása termékkategória-specifikus és nagyon erős például müszaki tudást feltételező termékek esetében, olyannyira, hogy hatása az országeredet-hatást részben felül is írhatja (vö. Chao 1993, Chandrasen-Paliwoda 2009). Textilipari termékeknél ezzel szemben a country-of-manufacturing (gyártási ország) és a country-of-parts (összetevők származási országa) országeredetek az árral, illetve a minőséggel kapcsolatos elvárásokat keltenek a fogyasztókban (Ha-Brookshire 2012). Az országeredet-hatással kapcsolatos kutatások eredményeit azonban befolyásolja a termékkategória, a termék összetettsége és bonyolultsága, de az az ország is, amelynek lakosai körében az országeredet-hatást vizsgálják (Hamzaoui-Essoussi \& Merunka 2006, Samli 2013).

Ezen országeredet-hatások müködéséhez azonban tudnunk kell, hogy melyik országból származik a termék (Aichner 2014). Ez többféleképpen is kommunikálható: jogilag szabályozott formában a 1) Made in .., felirattal és 2) eredetre utaló jelölésekkel, illetve jogilag nem szabályozott formában 3) az ország jelölésével a cégnévben (Hungaropharma), 4) adott ország nyelvéből származó szavakkal (Pöttyös), 5) az ország nyelvének használatával hirdetésekben vagy szlogenekben (Das Auto), illetve az országhoz köthető emblematikus - 6) híres emberek, 7) zászlók, 8) tájak és építmények - képekkel (Aichner 2014, 84-91). 
Az országeredet-hatást tehát adott ország nyelve is közvetítheti. Így például a francia nyelv a divat, az elegancia, a konyhamúvészet, a bor, a szépség és a nőiesség; a spanyol a szabadság, a kaland és a férfiasság; az olasz a finom ételek és a pozitív életszemlélet; míg a német a megbízhatóság, a pontosság és a fejlett (müszaki) technológia asszociációit hordozza (Hornikx et al. 2007, Hornikx \& van Meurs 2019, Kelly-Holmes 2005, Piller 2003). Ezeket az asszociációkat nem csupán a nyelv maga, hanem az adott nyelv egy eleme, így egy francia, olasz vagy német márkanév is előhívja (Kovács 2019). Az országeredet-hatás tehát egy márka - például „olaszos” vagy „németes” hangzású - nevével is kiváltható, akkor is, ha a márka nem adott országból származik. A szakirodalomban a jelenség neve Foreign Language Display (FLD). A tárgyalt jelenség az országeredet-hatásától annyiban tér el, hogy míg előbbi a márka származási országának hatását vizsgálja, addig az FLD esetében bármely nyelv - és a nyelven keresztül a kultúra és az ország - a márkához kapcsolható (Kovács 2019).

A következőkben az országeredet kérdését egy konkrét márkán, az Opelen vizsgáljuk meg. A márkával kapcsolatban asszociációs kutatásokat végzünk, és a következőket vizsgáljuk:

- mely gépkocsimárkákat társítják a válaszadók Franciaországgal, illetve Németországgal,

- az Opel márkával, illetve a francia és német autómárkákkal kapcsolatos asszociációk mennyiben egyeznek meg egymással.

\section{ANYAG ÉS MÓDSZER MATERIAL AND METHODS}

\section{Az Opel története dióhéjban The histroy of Opel in a nutshell}

Az Adam Opel által 1862-ben alapított vállalat kezdetben varrógépeket, majd az 1880-as évektől már kerékpárokat is gyártott, sőt, az Opel 1896ra a világ legnagyobb kerékpárgyártójává nőtte ki magát (Lüppens 2006, 173). Egy profilbővítés eredményeként 1899-ben kigördült az első gépkocsi is a gyárból. Az új terméket szintén kedvezően fogadták, így az Opel a 1920-as évekre Németország legnagyobb gépkocsigyártójává vált (Lüppens 2006).
A sikerek hatására a német családi vállalkozásba az 1920-as években folyamatosan vásárolta be magát az akkor már óriásvállalatnak számító General Motors. Az Opel gépjárművei megbízhatóságukról voltak híresek, olyannyira, hogy a gépkocsik megbízhatóságát vizsgáló tesztutakon (Zuverlässigkeitsfahrten) többszörösen kitüntették öket. Ezt a márkakommunikációban is felhasználták, amikor 1936-ban megalkották az „Opel a megbízható” („,Opel - der Zuverlässige“) szlogent (Lüppens 2006, 174).

Az 1950-es évektől az 1990-es évekig az Opel számos újítást vezetett be, miközben piaci részesedése is stabil volt. Az ezredforduló környékén azonban a márka németországi piaci részesedése csökkenésnek indult és 10 év alatt 17\%-ról 10\%-ra csökkent. Ennek okai valószínúleg a lassú reagálás a piaci folyamatokra; minőségi problémák és a dizájn háttérbe szorulása; valamint a nem egyértelmü márkaprofil és pozicionálás. Válaszlépésként a "Creative German engineering for better living" elvet szem elött tartva a márkát olyan innovatív, minőségi gépkocsikként pozicionálták újra, amelyeknek nem csak teljesítménye, hanem dizájnja is versenyképes lett. Az elsődleges célcsoportnak a 30-50 év között fiatal párokat tekintették, akik a gépkocsik esetében a költségeket, a biztonságot, a rugalmasságot és a családbarát jellemzőket tartják szem elött. Az újrapozicionálás meghozta az áttörést, mind a márka szakmai, mind a fogyasztói megítélésében (Lüppens 2006).

Közel 90 év után, 2017-ben a General Motors bejelentette, hogy eladja az Opel és a Vauxhall autómárkákat a PSA Groupnak. Az Opel márka megvásárlásával a magyar sajtó is foglalkozott, elsősorban a vállalat magyarországi érintettsége miatt, Szentgotthárdon ugyanis az 1990-es évek óta müködik Opel gyár, amely kezdetben Astra személygépkocsikat gyártott, míg ma motorok gyártásával foglalkozik (Opel 2020).

\section{Kérdōiv \\ Questionnaire}

Kutatásunkban elsődlegesen azt vizsgáljuk, hogy az Opel márkát a válaszadók - asszociációik alapján - inkább német („eredeti” országeredet) vagy inkább francia (,aktuális” országeredet) márkának tekintik-e. A kérdőívet 2019. tavaszán összesen 96 fö töltötte ki elektronikus úton. A kérdőív megosztása egy közösségi oldal személyes profilján, illetve egy Opel-kedvelö csoportban történt. A kitöltők 67,7\%-a (65 fö) férfi, 32,3\%, (31 fö) nő volt (Németh 2019). A kérdőív 20 db, autóipari 
marketinggel kapcsolatos kérdést tartalmazott. Jelen kutatásban az asszociációs módszert alkalmazó kérdéseket elemezzük.

\section{Asszociációs vizsgálatok Associations}

Asszociációk segítségével egy márka elmebeli pozícióját elemezhetjük. Ilyenkor a márka mint kognitív entitás jellemzőiből indulunk ki és feltételezzük, hogy a márka az elme részeként értelmezendő és elménkben fejti ki hatását (Esch 2004, Keller 1998, Kovács 2019).

A márka, mint kognitív entitás elemzése legtöbb esetben a márkához kapcsolódó, különböző fajtájú és erősségű asszociációk vizsgálatával történik (Franzen \& Bouwman 2001, Keller 1998, Kovács 2019). Asszociációs kutatások során egy szót vagy egy márkanevet prezentálunk az alanynak, majd megkérjük, hogy mondja ki, illetve írja le, milyen szó, vagy szavak jutnak eszébe a hívószóról. A márkához kapcsolódó asszociációk segítségével így meghatározhatjuk a márka helyét elménkben.

A márkához kapcsolódó asszociációk közül releváns az országeredetre utaló asszociáció (pl. BMW - német; vö. Aaker 1991), amely potenciálisan másodlagos asszociációkat kapcsol a márkához.

Másodlagos asszociációk azok az asszociációk, amelyek a márkával közvetlenül kapcsolatban lévő asszociációkhoz kapcsolódnak, így asszociációs láncok jöhetnek létre. Például: Milka (márka) csokoládé (közvetlen asszociáció) - tej (másodlagos asszociáció) - fehér (harmadlagos asszociáció)

A közvetett - másodlagos, illetve harmadlagos - asszociációk azért fontosak, mivel ezek a közvetlen asszociációkon keresztül kvázi-automatikusan szintén a márkához kapcsolódnak.
Egy konkrét példát alapul véve (Kovács 2019): az Alpecin (férfi) sampon szlogenje angol nyelven „German Engineering for your hair” (Alpecin 2016) - amely részben másodlagos asszociációkra épít. Német márkákkal kapcsolatosan jellemzőek a minőségi - főleg minőségi műszaki - termékekkel kapcsolatos asszociációk, mint a megbízhatóság, a tartósság és a jó minőség. A szlogennel, pontosabban a German és az engineering szavak kombinálásával ezeket a másodlagos asszociációkat viszi át a vállalat sikeresen egy FMCG-termékre, egy samponmárkára.

Az asszociációs vizsgálatokban alkalmazható módszerek közül (részletesen Kovács 2019) jelen kutatásban a következőket alkalmazzuk:

Irányított asszociáció (a megadható asszociációk fajtája korlátozva van):

Milyen német/francia autómárkák jutnak az eszébe?

Szabad asszociáció (a megadható asszociációk fajtája nincs korlátozva):

Milyen szavak jutnak az eszébe, ha német/francia autómárkákra gondol?

Mi az három dolog, ami eszébe jut az Opelröl, mint márkáról?

\section{EREDMÉNYEK RESULTS}

A „Milyen szavak jutnak az eszébe, ha német/francia autómárkákra gondol? " kérdésekre a kitöltők a német autómárkákat többségében pozitívan ítélték meg: a német autókat a megbízhatóság és a precizitás, a francia autókat pedig a jó dizájn és a kényelem pozitív tulajdonságok jellemzik (1. táblázat).

\section{1. táblázat: A német és francia autómárkák asszociációi}

Table 1. Associations of German and French automotive brands

\begin{tabular}{|c|c|c|}
\hline & Pozitív asszociációk (db) & Negatív asszociációk (db) \\
\hline Német autók & $\begin{array}{l}\text { megbízhatóság (36) } \\
\text { precizitás (17) } \\
\text { gyorsaság (7) } \\
\text { minőség (4) } \\
\text { erő (3) } \\
\end{array}$ & $\begin{array}{l}\text { drága vásárlási ár (16) } \\
\text { szervizelési igény (5) } \\
\text { dízel-botrány (4) }\end{array}$ \\
\hline Összesen & $67 \mathrm{db}$ & $25 \mathrm{db}$ \\
\hline Francia autók & $\begin{array}{l}\text { kényelmes (19) } \\
\text { design (14) } \\
\text { drága (6) } \\
\text { modern (5) }\end{array}$ & \begin{tabular}{|l} 
túlbonyolítottság (30) \\
elektromos/elektronikus hibák (13)
\end{tabular} \\
\hline Összesen & $44 \mathrm{db}$ & $43 \mathrm{db}$ \\
\hline
\end{tabular}

Megjegyzés: Az azonos jellemzöre utaló különböző megnevezéseket összevontuk.

Forrás: Németh 2019 
A második, asszociációkkal kapcsolatos kérdés az volt, hogy milyen francia, illetve német gépkocsimárkákat tud felsorolni a válaszadó. Országonként legfeljebb 3 márka megadására volt lehetőség (2. táblázat).

2. táblázat: Első asszociáció és összes asszociáció a francia autómárkák esetén Table 2. First association and all associations for French car brands

\begin{tabular}{|l|l|l|}
\hline Francia márka & $\begin{array}{l}\text { Első helyen megnevezett } \\
\text { asszociációk száma (db) }\end{array}$ & $\begin{array}{l}\text { Összesen megnevezett } \\
\text { asszociációk száma (db) }\end{array}$ \\
\hline Peugeot & 35 & 49 \\
\hline Renault & 34 & 48 \\
\hline Citroën & 19 & 56 \\
\hline Opel & - & 3 \\
\hline
\end{tabular}

Forrás: Németh 2019

A kitöltők 5\%-a nem nevezett meg semmilyen francia gépkocsimárkát, illetve tévesen gondolt egy márkát franciának. A válaszok között megjelent a Renault csoporthoz tartozó Dacia, illetve a már a Volkswagenhez tartozó - eredetileg francia Bugatti luxusautó-márka is.
Német autómárkaként legtöbb esetben a válaszadók az Opel márkát nevezték meg (3. táblázat). Két kitöltő válaszában bizonytalan volt, és ezt zárójelben jelezte: ,vagy francia?”.

3. táblázat: Első asszociáció és összes asszociáció a német autómárkák esetén Table 3. First association and all associations German car brands

\begin{tabular}{|l|l|l|}
\hline Német márka & $\begin{array}{l}\text { Első helyen megnevezett } \\
\text { asszociációk száma }(\mathbf{d b})\end{array}$ & $\begin{array}{l}\text { Összesen megnevezett } \\
\text { asszociációk száma }(\mathbf{d b})\end{array}$ \\
\hline Opel & 31 & 71 \\
\hline Volkswagen & 19 & 68 \\
\hline BMW & 12 & 63 \\
\hline Mercedes & 14 & 63 \\
\hline Audi & 10 & 59 \\
\hline Seat & - & 3 \\
\hline Škoda & - & 3 \\
\hline
\end{tabular}

Forrás: Németh 2019

A Volkswagen konszernhez köthető márkák közül a válaszokban megjelentek a konszernhez tartozó további márkák is, a Porsche és a Seat. Utóbbi azért releváns, mivel a márka „eredeti” országeredete nem Németország, hanem Spanyolország. Még érdekesebb a Škoda márka, amelyre így részben német márkaként tekint a válaszadók egy része, holott a márkát legtöbben Csehszlovákiához/Csehországhoz kapcsolnánk, annak ellenére, hogy a Škoda alapításakor (1895) a cég székhelye,
Mlada Boleslav az osztrák-magyar monarchia része volt (Randle 2002).

A kérdőívet kitöltők 74\%-a német autóként tekint $\mathrm{ma}$ is az Opelre, annak ellenére, hogy az Opelt 90 éve megvásárolta a General Motors, majd 2017-ben a francia PSA-csoport.

A következő kérdésben arra kerestük a választ, hogy szabad asszociációként mi az első három szó, ami a válaszadók eszébe jut az Opel márkáról (1. ábra). 


\section{1. ábra: Az egyes asszociációk megoszlása az Opel márkára \\ Figure 1. Associations to Opel}

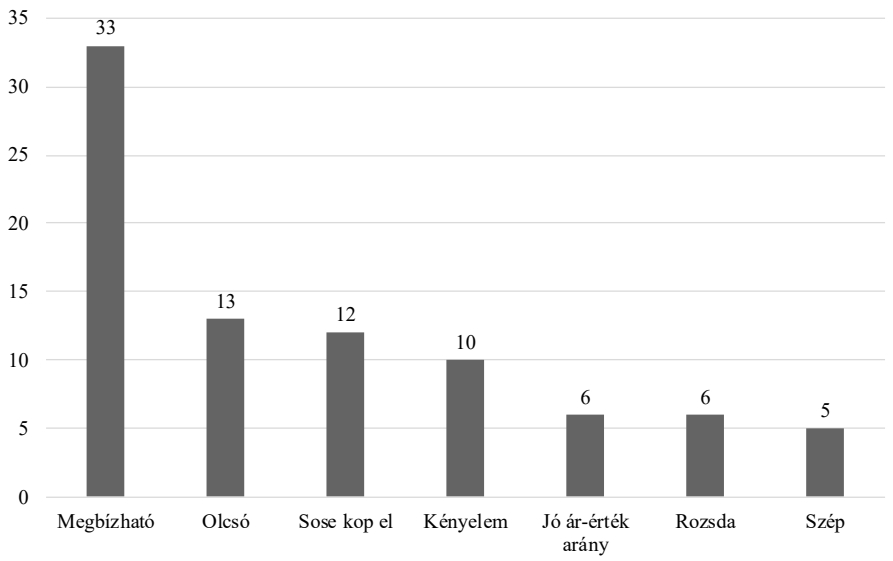

Forrás: Németh 2019

Releváns a népszerüvé vált magyar „szlogen”, az Opel - sose kop el, amely szintén a márka megbízhatóságára utal. Ezzel az Opel, mint látjuk, közelebb áll a német gépkocsimárkákkal kapcsolatos asszociációkhoz, ugyanis a német autók esetében is a megbízhatóság volt az elsődleges jellemző (lásd 1. táblázat). Az Opel márkára asszociációként a megbizható jelző valamint a sose kop el ,szlogen” Kovács (2019) márkaasszociációs kutatásaiban is előfordult, utóbbi a Sose kOpel (sic!) formában is.

Utolsó lépésként megvizsgáltuk, hogy mi a véleményük azoknak a kitöltőknek az Opelröl, akiknek ilyen márkájú autójuk (is) van (2. ábra).

\section{2. ábra: Az Opel-tulajdonosok véleménye az Opelről}

Figure 2. Opel users' opinion of Opel

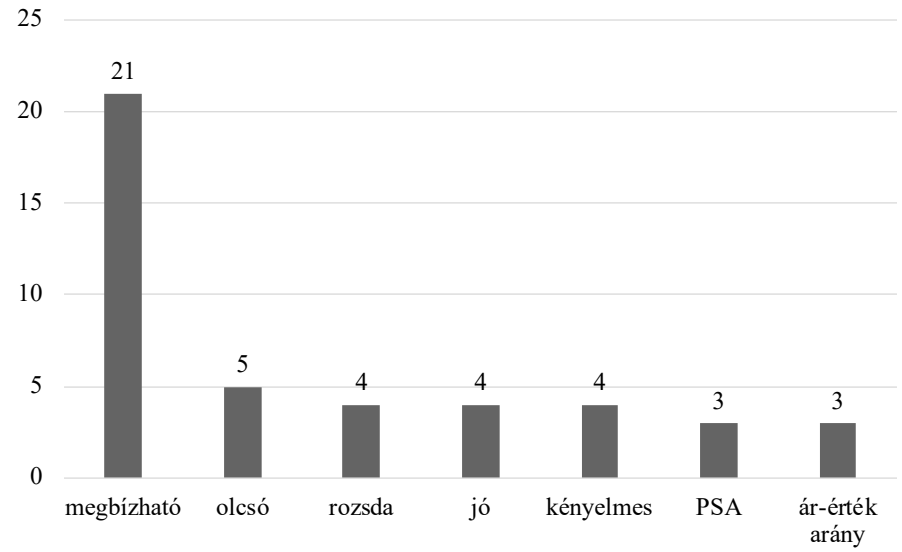

Forrás: Németh 2019 
A kitöltők közül 41 fö rendelkezik Opellel. Ez esetben, mint látjuk, a megbízhatóságról kialakult kép kedvezö, azonban a(z) (anyag)minőségre (is) utaló rozsda asszociáció negatív. Hozzá kell tennünk azonban, hogy Magyarországon az Opel autók átlagéletkora 15,3 év (KSH 2019a). A kutatásban részt vevők esetében az általuk birtokolt Opel gépjárművek életkora 15,2 év (Németh 2019). A rozsda szó negatív tartama így relatív: egy 15 éves, vagy idősebb autó esetében a rozsda megjelenése nem szükségszerüen jelenti azt, hogy az autó nem megfelelő minőségű. Az asszociációk között az Opel jelenlegi tulajdonosának, a PSA konszernnek a neve is megjelent.

\section{KÖVETKEZTETÉSEK CONCLUSIONS}

A fenti eredmények alapján kijelenthetjük, hogy az Opel márkát a válaszadók német márkaként azonosítják. Egyrészt a német autómárkák felsorolását kérő kérdésre legnagyobb számban az Opel került megnevezésre, másrészt a német gépjármüvekkel kapcsolatos asszociációk és az Opel legerösebb asszociációja (megbízhatóság) azonosak.

A megbízhatóság megfelel a német müszaki termékekkel kapcsolatos általános képnek: Németországot a minőséggel, a megbízhatósággal, valamint a precizitással kapcsoljuk össze, és a német technológiai színvonal képének hordozói az Audi, a BMW és a Mercedes márkák. Ezzel szemben Franciaországot a magas minőségü élettel hozzuk kapcsolatba, asszociációk szempontjából erős a francia öntudat, az országot francia parfümmel, a nyelvvel, a konyhával és többek között a Lafayette, a Dom Perignon és a Chanel márkákkal, illetve a luxustermékekkel kötjük össze. A francia országeredet a bor, a divat, illetve a parfüm termékkategóriákban - hedonisztikus termékek esetében pozitív képeket hív elő, a gépkocsik, illetve egyéb fejlett technikai eszközök termékkategóriáinak esetében azonban az előhívott képek már nem mindig tekinthetőek pozitívnak (Andéhn \& L'Espoir Decosta 2018).

Jelen esetben kérdés, hogy a megbízhatósággal kapcsolatos kedvező asszociációkat mi váltja ki?

- Amennyiben az országeredet-hatás az azonos asszociációk oka, akkor a német gépjármüvekre vonatkozó általános asszociációkat vitték át részben a válaszadók a márkára: „az országeredet-imázs nehezen választható el a márkaimázstól (pl. a német autó imázsa az, hogy tartós, így ezáltal az Opelt is tartósnak vélik a fogyasztók)" (Malota 2004b, 123). Ez megfelel a korábban kifejtett országeredet-hatásnak. Ezen kontextusban lesz kiemelt szerepe a korábban említett másodlagos - a márkához nem közvetlenül kapcsolódó - asszociációknak: ha a márkát a fogyasztó elméjében sikeresen kapcsoljuk egy országhoz, akkor egyúttal az országhoz kapcsolódó pozitív asszociációkat is át tudjuk vinni a márkára.

- Amásik lehetőség az asszociációk átvételének ellenkező iránya: az egyéni, személyes tapasztalatokat (Opelt vettem, és megbízható) vetítik ki a válaszadók az országból érkezö, azonos termékkategóriába tartozó termékekre. Habár az asszociációk és a jellemzők átadásának ezt az irányát sokszor figyelmen kívül hagyjuk, könnyen belátható, hogy pont ezen irány alapján jönnek létre hosszú távon azok a sztereotipikus asszociációk, amelyek az egyes országokból származó termékeket jellemezhetik. Jelen esetben ez az átadási irány azért is megfontolandó, mivel a Magyarországon legnagyobb számban forgalomba lévő autómárka 2002 óta az Opel (KSH 2019b).

Az Opel esetén, annak ellenére, hogy országeredet szempontjából hibrid termékről beszélhetünk (Németország, Egyesült Államok, Franciaország; de akár Magyarország is, mint az összeszerelés, vagy alkatrész országa) a márkát elsősorban Németországgal, és a termék jellemzőit a német gépkocsik jellemzőivel azonosítjuk.

Ez az eredmény nem volt evidens: a Suzuki Magyarországon - nem csak japán autónak tekinthető. A márka valószínúsíthető kettős identitását asszociációk támasztják alá: a márka leggyakoribb asszociációi között mind a japán (erősebb kapcsolat), mind a magyar (gyengébb kapcsolat) szerepel (Kovács 2019). Ezt a hatást a reklámok is erősítik: az 1990-es évek „A mi autónk” szlogen esetében a „mi” utal a magyar kontextusra is. A kettős eredet 2012-ben „Igazi magyar. És japán.” felirat és szöveg formájában jelent meg reklámokban.

Marketingkommunikációs eszközök az Opel esetében is erősítik a márka német gyökereit, például magyarul a "Német minőség mindannyiunknak" kijelentéssel. Hasonló tartalom más nyelvü hirdetésekben is előfordul 2010 és 2019 között, ha nem is visszatérö elemként; illetve a korábbi, német nyelvű szlogen - „Wir leben Autos” - is a márka német eredetére utalt. Arra nem találtunk példát, hogy hirdetésekben az aktuális francia országeredetet hangsúlyoznák. 
Mindezek a példák jól mutatják, hogy az országeredet nem minden esetben egyértelmü. Hogy tovább bonyolítsuk a képet, nem csak valós, hanem vélt országeredetről is beszélhetünk, amely részben a korábban leírt Foreign Language Display segítségével érhető el. Egyéb információ hiányában a Trattoria Alfredo, az Alesro és a G. Bellini olasz, a Vita D'Or és a Chêne d'Argent francia márka a valóságban azonban ezek egy német diszkontáruház kereskedelmi márkái, tehát németek (Lidl 2020, Langner \& Esch 2019).

Fentiek alapján feltételezzük, hogy az országeredet kérdése legalább négy kontextust és négy összefüggést takarhat:

1. Eredeti országeredet: ahonnan a márka eredetileg származik; a vállalat, illetve márka alapításának helye.

2. Aktuális országeredet: az ország, amelylyel a márkát aktuálisan összekapcsoljuk; a márka aktuális tulajdonosi székhelye.
3. Sugallt országeredet: azon ország, amelyről a márka tulajdonosa - például márkanév alapján, képekkel - szeretné, hogy országeredetnek tekintsük (pl. FLD).

4. Vélt országeredet: az az ország, amelylyel a márkát - például név alapján helyesen vagy helytelenül a fogyasztó összekapcsolja.

$\mathrm{Az}$ itt javasolt négy országeredet-összefüggést el kell választanunk a tanulmány elején leírt országeredet-fajtáktól: míg azok a megközelítések az országeredet alkotóelemekre bontását jelentik, addig jelen felosztás az országeredetet mind a négy esetben egységesen kezeli - természetesen feltételezve, hogy mind a négy esetben ez az egységes kép a fent említett komponensek egymásra hatásának eredményeként is létrejöhet (3. ábra).

\section{3. ábra: Az országeredet-hatás befolyásoló elemei \\ Figure 3. Influencing elements of the country-of-origin effect}

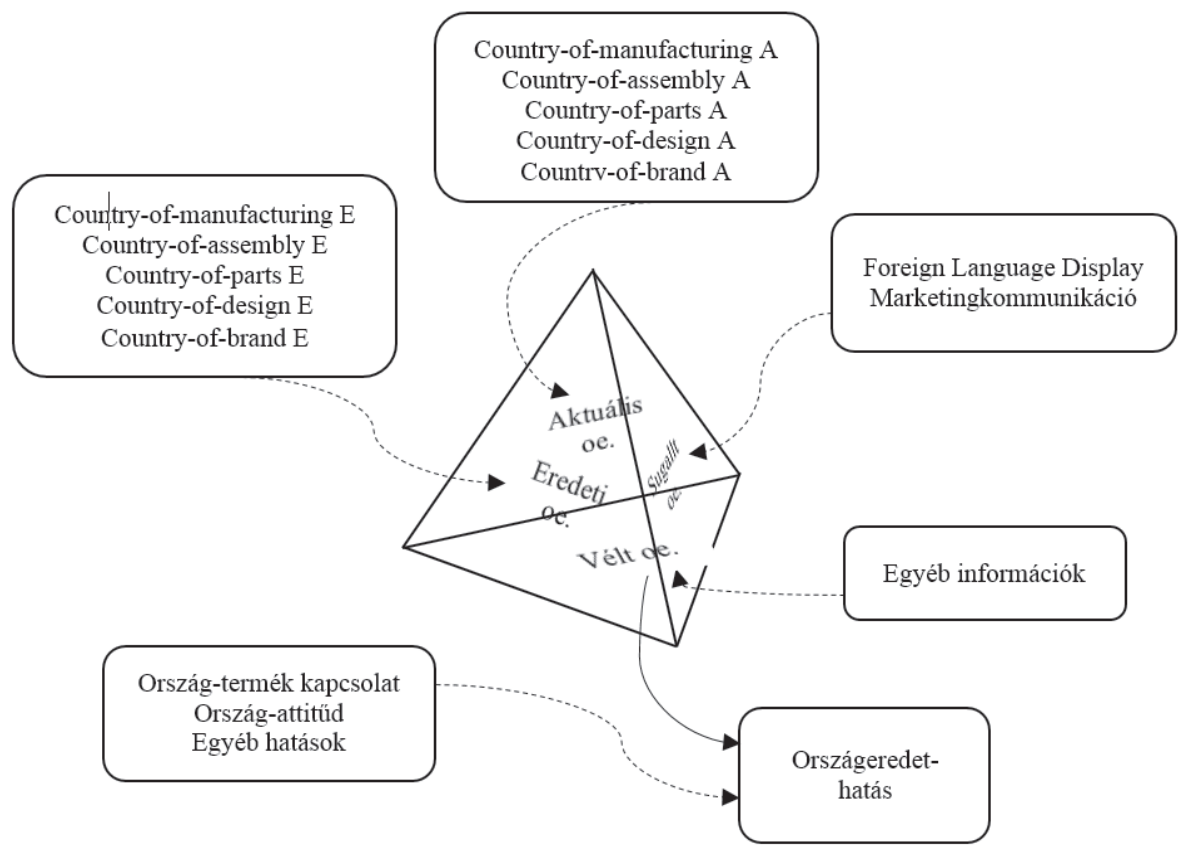

Megjegyzés: $A=$ aktuális, $E=$ eredeti, oe=országeredet

Forrás: saját szerkesztés 
Az ábrán az országeredet-hatást befolyásoló tényezőket ábrázoljuk egy komplex tetraéderformában. A térbeli forma azért szükséges, mivel bármelyik elem bármelyik elemmel kapcsolatba léphet. A szaggatott vonallal jelölt nyilak arra utalnak, hogy ezek az információk nem szükségszerüen léteznek, vagy ismertek; ennek ellenére az országeredetről legtöbb termék esetében van - helyes vagy helytelen - elképzelésünk.

A sugallt országeredet ebben a kontextusban a valós országeredet elrejtésére szolgálhat, és marketingkommunikációs eszközök hatására jön létre (lásd fenti kereskedelmi márkákat).

A vélt országeredet a fogyasztó által származási országnak gondolt ország, amellyel a fogyasztó a márkát összeköti a három másik - eredeti, aktuális, sugallt - országeredet, illetve egyéb információk hatására. A vélt országeredet bármely másik országeredettől eltérhet, amelyre kiváló példa a French's Mustard márka, amelynek értékesítési számait a 2000-es évek elején az Egyesült Államokban uralkodó franciaellenes hangulat negatívan befolyásolta, mivel a neve alapján francia márkának vélték - annak ellenére, hogy az egyesült államokbeli márka és nevét Robert Timothy Frenchröl, a márka alapítójáról kapta (Rivkin \& Sutherland 2004).

\section{JAVASLATOK RECOMMENDATIONS}

Az országeredet ezen négy fajtáját azért lényeges tudatosítanunk, mivel ezek mindegyike felhasználható arra, hogy a márkát egy adott országhoz kapcsoljuk és az országgal kapcsolatos pozitív képeket áttranszferáljuk a márkára.

Kérdésként merül fel, hogy elképzelhetö-e, hogy kihasználjunk egyszerre több országeredet-hatást?

Erre a kérdésre nehéz válaszolni. A nem egyértelmü - nem megfelelően kommunikált - országeredetek ahhoz vezethetnek, hogy az adott országokkal kapcsolatos pozitív asszociációkat nem tudjuk átvinni a márkára, és így a kettős képpel a potenciális vásárlót elbizonytalanítjuk.

Megfelelő kommunikációval - és itt ki kell hangsúlyoznunk a kommunikáció elsődleges szerepét - azonban elképzelhetö, hogy egyszerre több ország pozitív asszociációit is átvigyük a márkára. Erre kiváló példa a Seat márka, amely spanyol márkaként a német Volkswagen konszern része és amelynek külföldi hirdetései részben a márka ezen kettősségére utalnak és kihasználják a kettősségből származó előnyöket a „Spanish Design - German Engineering" szlogennel.

A kutatás alapján az Opel esetében fenti mintára így javasoljuk magyar nyelven az alábbi szlogen-, illetve márkanyelv-elemek megfontolását (4. táblázat).

4. táblázat: Javasolt nyelvi elemek az Opel német, illetve francia országeredetének kommunikálására

Table 4. Suggested language elements for communicating Opel's German and French origins

\begin{tabular}{|c|c|}
\hline Német országeredet & Francia országeredet \\
\hline német precizítás & francia dizájn \\
\hline német minőség & francia kényelem \\
\hline német megbízhatóság & francia luxus \\
\hline
\end{tabular}

Forrás: saját kutatás 
Ezen elemek egymással kombinálhatóak is lehetnek, így a Seat mintájára alkothatna az Opel olyan szlogent, amely a márka német eredetét és müszaki megoldásait a mai francia tulajdonossal és a francia gépkocsik jellemzőivel kapcsolja össze, például: Német minőség - francia kényelem formában. Ezzel a PSA mindkét országeredet pozitív asszociációira építve pozicionálhatná - egyedien - a márkát. A kettős országeredet-hatás hangsúlyozásának hatékonysága azonban minden egyes típus esetében külön megfontolandó (vö. pl. Opel haszongépjárművek).

Az Opelnek azonban a jövőben ügyelnie kell arra is, hogy a francia autókkal kapcsolatos negatív sztereotípiák ne kapcsolódjanak a márkához: ideális esetben tehát a márkának úgy kellene megtartania a német autókhoz kapcsolódó pozitív asszociációkat, hogy közben a francia autókra és francia termékekre jellemző asszociációkra is épít. Fontos azonban ehhez, hogy a márka által kínált minőség - a megbízhatóság alapja - változatlan maradjon.

\section{ÖSSZEFOGLALÁS SUMMARY}

Jelen tanulmányban az országeredet egyes kérdéseit tárgyaltuk és kapcsoltuk össze asszociációs vizsgálatokkal az Opel márka példáján keresztül. Rámutattunk, hogy a márkára ma is elsősorban német márkaként tekintenek, annak ellenére, hogy az az 1930-as évek óta nem német tulajdonban van.

Az eredmények alapján kifejtettük, hogy az országeredet legalább négy összefüggésben eredeti, aktuális, sugallt, vélt - értelmezhető, és ezen kontextusok mindegyike felhasználható arra, hogy az országeredet-hatást kihasználva egy márkára egy ország sztereotipikus jellemzőit átvigyük.

A kutatás korlátja, hogy a bemutatott eredmények csak egy márka asszociációinak kis mintás vizsgálatán alapulnak. Az egyik limitáció így a válaszadók kis száma, illetve megoszlása: nagyobb, illetve reprezentatív mintán is szükséges lenne a kutatást elvégezni. Limitációként tekinthetünk továbbá az adatfelvétel országára: a márka országeredet-megítélését befolyásolja a válasz- adók „viszonya“ a (vélt) országeredet országához. Magyarország kulturális jellemzőinek - maszkulin, és nagymértékben bizonytalanságkerülő kultúra a német és az olasz gépkocsimárkák felelnek meg leginkább (De Mooij 2004); így az Opel pozitív megítélése részben általános kulturális jellemzőkkel, és nem feltétlenül csak a márka jellemzőivel lehet magyarázható. Ennek igazolásához azonban további német márkák asszociációinak vizsgálata szükséges. A harmadik limitáció abból ered, hogy csak egy márkát vizsgáltunk. A jelenség pontosabb megértéséhez szükséges más hibrid autóipari márkák - például Dacia (román/francia), Seat (spnayol/ német), Škoda (cseh/német) - esetében is vizsgálatokat végezni. A negyedik limitáció szintén abból ered, hogy egy márkát vizsgáltunk, amely márka középkategóriás gépkocsimárka. Fontos lenne a vizsgálatokat a gépkocsik termékkategórián belül kiterjeszteni más szegmensekre (például luxus-sportautókra Bugatti - francia/német; Lamborghini - francia/német), illetve más termékkategóriákra is (például motorkerékpárokra Ducati - olasz/német).

A kutatás folytatása így nagyobb mintán, több márkával képzelhető el, az Opel esetében a későbbi kérdőívben elemezve az egyesült államokbeli autómárkákkal kapcsolatos asszociációkat is, amely jelen kutatásból kimaradt. Szintén vizsgálandó, hogy a megkérdezettek véleményét befolyásolja-e, ha tudatosítjuk bennük, hogy az Opel jelenleg francia márka.

Az országeredet fenti négy kontextusa további, termékkategória-specifikus vizsgálatokat igényel ahhoz, hogy ezen országeredeteknek, valamint az országeredet különböző összetevőinek egymásra hatását pontosabban megérthessük. 


\section{HIVATKOZÁSOK REFERENCES}

Aaker, D. A. (1991), Managing Brand Equity, New York: Free Press

Adina, C., Gabriela, C. and Roxana-Denisa, R. (2015), "Country-of-Origin Effects on Perceived Brand Positioning", Procedia Economics and Finance, 23, 422-27, DOI: 10.1016/ s2212-5671(15)00383-4

Aichner, T. (2014), "Country-of-origin marketing: A list of typical strategies with examples", Journal of Brand Management, 21, 81-93, DOI: $10.1057 / \mathrm{bm} .2013 .24$

Alpecin (2016), http://www.alpecin.co.uk/en/ (letöltés: 2016.12.17.)

Andéhn, M. and L'Espoir Decosta, J. (2018), "Re-imagining the country-of-origin effect: a promulgation approach", Journal of Product \& Brand Management, 27(7), 884-896, DOI: 10.1108/jpbm-11-2017-1666

Chandrasen, A. and Paliwoda, S. J. (2009), "Country of Assembly (COA) effect on perceived automobile quality: a Thai consumers' perspective", Journal of Marketing Management, 25(56), 483-499, DOI: 10.1362/026725709X461812

Chao, P. (1993), "Partitioning Country of Origin Effects: Consumer Evaluations of a Hybrid Product", Journal of International Business Studies, 24(2), 291-306, DOI: 10.1057/palgrave.jibs. 8490851

De Mooij, M. (2004), Consumer Behavior and Culture, Thousand Oaks, CA: Sage

Esch, F.-R. (2004), Strategie und Technik der Markenführung, 2. Aufl. München: Franz Vahlen

Franzen, G. and Bouwman, M. (2001), The Mental World of Brands, Henley-on-Thames: World Advertising Research Center

Ha-Brookshire, J. E. (2012), "Country of Parts, Country of Manufacturing, and Country of Origin: Consumer Purchase Preferences and the Impact of Perceived Prices", Clothing and Textiles Research Journal, 30(1), 19-34, DOI: $10.1177 / 0887302 \times 11433502$

Hamzaoui-Essoussi, L. and Merunka, D. (2006), "The impact of country of design and country of manufacture on consumer perceptions of bi-national products' quality: An empirical model based on the concept of fit", Journal of Consumer Marketing, 23(3), 145-155, DOI: $10.1108 / 07363760610663303$

Hornikx, J., van Meurs, F. and Starren, M. (2007), “An Empirical Study of Readers' Associations with Multilingual Advertising: The Case of
French, German and Spanish in Dutch Advertising", Journal of Multilingual and Multicultural Development, 28(3), 204-219, DOI: 10.2167/ jmmd 482.0

Hornikx, J., van Meurs, F. (2019), Foreign Languages in Advertising, Cham: Palgrave Macmillan, DOI: 10.1007/978-3-030-31691-4

Keller, K. L. (1998), Strategic Brand Management, New Jersey: Prentice Hall

Kelly-Holmes, H. (2005), Advertising as multilingual communication, NewYork: Palgrave Macmillan

Kovács L. (2019), Márka és márkanév. Budapest: Tinta

KSH (2019a), A személygépkocsi-állomány átlagos kora gyártmányok szerint (2002-), https:// www.ksh.hu/docs/hun/xstadat/xstadat_eves/i ode002.html (letöltés: 2019.05.02.)

KSH (2019b), A személygépkocsi-állomány gyártmány szerint (2002-), https://www.ksh.hu/ docs/hun/xstadat/xstadat_eves/i_ode001b.html (letöltés:2019.05.02.)

Langner, T. and Esch, F.-R. (2019), "Branding als Grundlage zum Markenaufbau”, in: Esch, F.-R. (Hrsg.), Handbuch Markenführung, Wiesbaden: Springer Gabler. 587-604, DOI: 10.1007/978-3658-13342-9 28

Lidl (2020), Eigenmarken Food, https:// www.lidl.de/de/eigenmarken-food/c4663 (letöltés:2020.03.21.)

Lüppens, M. (2006), Der Markendiamant, Wiesbaden: Gabler, DOI: 10.1007/978-3-83499229-1

Malota E. (2004a), „Országeredet imázs I”, Marketing \& Menedzsment, 38(4), 49-60

Malota E. (2004b), „Országeredet imázs II”, Marketing \& Menedzsment, 38(6)-39(1), 122-130

Matarazzo, M. (2012), Country of origin effect: research evolution, basic constructs and firm implications, In: Bertoli, G., Resciniti, R. (eds.) International Marketing and the Country of Origin Effect, Cheltenham--Northampton: Edward Elgar. 23-42, DOI: $10.4337 / 9781781955611.00008$

Németh T. (2019), Egy személygépkocsi gyártó vállalat termékportfóliója 2019-ben, Szakdolgozat, Szombathely: Eötvös Loránd Tudományegyetem.

Opel 2020, „Rólunk” https://www.opel.hu/aboutopel/Szentgotthard/rolunk.html 82020 (letöltés: 2020.03.10)

Papp-Váry Á. (2004), Országok márkái, márkák országai - Az országeredet-hatás elmélete és gyakorlata: Az országeredet-hatás elmélete és gyakorlata, In: Czagány L., Garai L. (szerk.), 
A szociális identitás, az információ és a piac, Szeged: JATEPress, 297-315

Papp-Váry Á. (2017), „Országmárkázástól a versenyképes identitásig - és még tovább. A country branding megjelenése, céljai és természete 2009-ben és 2017-ben”, Marketing \& Menedzsment, 50(1-2), 105-116

Papp-Váry Á. (2019), Országmárkázás, Budapest: Akadémiai

Piller, I. (2003), „Advertising as a Site of Language Contact", Annual Review of Applied Linguistics, 23, 170-183, DOI: 10.1017/ s0267190503000254
Randle, D. (2002), The true story of Skoda, Phoenix Mill: Sutton

Rivkin, S. and Sutherland, F. (2004), The Making of a Name, Oxford, New York: Oxford University Press

Samli, A. C. (2013), International Consumer Behavior in the 21st Century, New York: Springer, DOI 10.1007/978-1-4614-5125-9

Törőcsik M. - Somogyi Z. (2009), „Az országmárkázás kérdései”, Marketing \& Menedzsment, 43(2), 20-29

Kovács László, egyetemi docens kovacs.laszlo@sek.elte.hu

Németh Tamás, BA szakos hallgató nemeth.tamas97@gmail.com

Eötvös Loránd Tudományegyetem, Társadalomtudományi Kar Savaria Gazdálkodástudományi Tanszék

\section{Country-of-origin effect or country-of origin effects? Considerations based on the example of Opel}

\section{THE AIMS OF THE PAPER}

The aim of the study is to show through the results of a brand association research that in many cases the country-of-origin effect cannot be simplified to the effect of one country: it is possible that for a product several countries of origin compete with each other. These competing country-of-origin effects need to be emphasized since, when used properly, they can be used for brand positioning.

\section{METHODOLOGY}

In the empirical part of the study, some aspects of the country-of-origin effect are examined through the brand Opel. Free and guided associations were collected 2019 online, both for the product category cars - connected to the country of origin - and for the brand name.

\section{MOST IMPORTANT RESULTS}

According to the results, Opel is still considered by the respondents as a German brand: they explicitly refer to it as a German brand, and their brand associations also align with those of German car brand. Based on the results and on previous research the paper also points out that the question of country origin can be examined in at least four contexts: original country-of-origin, current country-of-origin, suggested country-of-origin and perceived country-of-origin.

\section{RECOMMENDATIONS}

Based on the results, we suggest that emphasizing the dual country-of-origin of Opel (German and French) could be a key component in marketing communications and brand language. Emphasizing dual country origins allows for a unique positioning that combines favorable associations from both countries.

Keywords: Opel, country-of-origin, associations, country-of-origin effect 